\title{
Assongka Bala: Interpretation of Value Systems in Handling Disease Outbreaks in the Bugis-Makassar Society
}

\author{
Syamsu Rijal ${ }^{1}$,Syamsidar ${ }^{2}$, Muh. Zainuddin Badollahi ${ }^{1}$ \\ ${ }^{1}$ Lecturer Politeknik Pariwisata Makassar, \\ ${ }^{2}$ Lecturer, Institusi Agama Islam Negeri Kendari
}

Corresponding Author: Syamsu Rizal

Email: rijal@poltekparmakassar.ac.id

Article Info

Article history:

Received 10 April 2020

Received in revised form 18

April 2020

Accepted 24 April 2020

Keywords:

Value System

Disease Mitigation

Ritual

Sanro

\begin{abstract}
This research is motivated by the phenomenon of pandemic disease outbreaks, treatment or prevention patterns carried out by the BugisMakassar community, although they have been equipped with modern knowledge about the handling of disease outbreaks, they still do some ritual outbreaks in which each of these rituals is called Assongka Bala led by a person called Sanro. This study uses a qualitative research method with a descriptive approach to describe the role of Sanro in Assongka Bala rituals, data collection techniques used are interviews and observation. This study aims to: Describe the role of Sanro in the ritual handling of outbreaks in the Bugis-Makassar community. The role of Sanro in Sanro's knowledge of ritual prevention and treatment of disease outbreaks in his community as well as knowledge of ritual management performed so that people who believe in needing a Sanro to lead the ritual. The Bugis-Makassar community, in their practice of life, is related to the social, cultural and handling of disease outbreaks, the community has a belief in the rituals of Assongka Bala which then becomes traditional values that affect their knowledge about handling epidemics and also influences their behavior in maintaining health, namely the behavior system is generally divided into two types, namely in the family environment and customary environment
\end{abstract}

\section{Introduction}

South Sulawesi is one of the provinces in Indonesia that is classified as a compound. This is based because in this area inhabited by several different. One that is in South Sulawesi is BugisMakassar. The social and cultural life of the Bugis-Makassar community as is the case with other communities in Indonesia is very laden in the application of traditional value systems in daily life as the majority identity in South Sulawesi. Outside communities who know the BugisMakassar community consider them to be a mysterious, conservative and full of traditional cultural values. This assumption is based on reality in exclusive behavior, especially in traditional ceremonies in Bugis-Makassar.

As it is known that humans in their lives are often faced with various problems, both individually and in groups or communities. In solving problems, various ways he does, including their belief in the magical power that surrounds it. One of them is making peace with 
nature through a series of rituals or ceremonies. For rituals or ceremonies carried out aiming to achieve a peaceful, safe, peaceful and prosperous life (Hasbullah et al., 2017).

Modernity is often associated with belief in the dogma of rationality, while the phenomenon of the rise of traditional treatment or prevention of epidemics in people who use the services of traditional healers and clerics is often seen as irrational behavior. (Hadisaputra, 2016) explained that the belief in shamans and shamanic practices are local beliefs that are embedded in the culture of a society. As local beliefs, continued Kapferer, both of them cannot be judged from the rationality of science because it has its reason and logic, rationality behind irrationality.

Rituals related to beliefs in certain graves, places, and objects are led by a Sanro '. The BugisMakassar community considers that the ritual of rejecting (Assongka Bala) is a form of ceremony that contains the belief of preventing or treating the village and its people. This ritual is a symbolic behavior or action as well as a form of expression of their souls in a relationship with the inhabitants of the unseen world. The implementation of the Assongka Bala ritual is also a fulfillment of the "promise or agreement" that their ancestors had made with supernatural beings. The agreement contains mutual care and does not interfere with each other. As a realization of the promise. People believe that if this is violated (rituals are not carried out), there will be various kinds of interference from spirits (Rismawati, 2014).

Various rituals are performed to invoke and worship the gods. The Massompa worship rituals are called: Assongka Bala, Massorong, Mappaenre, Mattoana, Millau Bosi, Mattedduk Arajang, Mappedaung Arajang, Manre Sipulung, Maddoja Bine, Mappalili, and Mappalettuk. This kind of ritual is attended by some communities and is usually attended by all local people. In practice, Assongka Bala mixes elements of Islam, Hinduism, Animism, and Dynamism. This is seen from the presence of offerings and recitation of spells aimed at getting help from spirits. Yakub (1972) explains about some elements of Hindu belief that are still found in some Indonesian Islamic societies, including (1) worshiping the spirits of ancestors, (2) spells of shamans by worshiping ghosts and gods, (3) burning incense in incense, and (4) sowing flowers at intersections (Laila, 2018).

The community performs the Assongka Bala ritual as an effort to preserve the Bugis-Makassar culture, this is in line with the historical tradition of the Assongka Bala ritual as an ancestral heritage that deserves to be preserved and preserved. Also, as an effort to preserve the BugisMakassar tradition to maintain the relationship between humans and the environment, humans with the supernatural. Assongka Bala ritual is known by the public which aims to reject reinforcements. Assongka Bala is strengthened in Indonesian with the word rejection or safety. (Kusumah, 2017) said that the Assoongka Bala tradition is a community tradition that was born from community activities several centuries ago that colored human culture. The timing of Assoongka Bala rituals in the Bugis-Makassar community is different based on the beliefs and habits inherited from their ancestors.

Research on the handling of disease outbreaks in Bugis-Makassar has been widely carried out. Especially research in the field of existence of beliefs in cultural values of the Bugis-Makassar people, the environment to the role of the government in preserving the culture of the Bugis Makassar community. Knowledge of the human body, especially when medical science was not as developed as it is today, is very much needed and is often already widely known by the public. In the village, people who usually heal sick people are called shamans, masseurs. A knowledgeable shaman is called a shaman, this shaman usually uses a lot of occult knowledge, 
besides they also have a lot of knowledge about the characteristics of the human body, location, and composition of veins, etc. (Jannah \& Zurinani, 2017; Teng, 2019).

The Bugis-Makassar society can overcome fever in various ways, including by grating a young banana, then sticking it to the head, or finely grinding the tawak, then sticking it to the head. I can also drink pumpkin oil in the morning. Or by cooking sesame oil and henna oil until the water runs out, mixed, then drunk. Another way is to mix acid, sugar, and jalawe, then eat in the morning or when going to sleep. There is another by grinding the guava buds, pouring it with hot water, then drink it. The last way can be by mixing rice water washing first with hazelnut, then drink (Oktaviani et al., 2019).

The value of local wisdom contained in the Assongka Bala's call by the Bugis-Makassar community in the past where the community believes that all forms of disasters including disease outbreaks are the will of the creator almighty will reduce disasters as a form of warning if humans commit crime and damage, and vice versa and will make human life prosperous if humans do good. For this reason, in handling any disasters, including epidemics inflicted on the community, humans must apologize and improve themselves by performing traditional rituals, one of which is Assongka Bala.

In the implementation of the Assongka Bala ritual, the ritual is led by traditional stakeholders with procedures governed by norms and values such as burning coconut fiber, betel leaves, and lanra leaves' which are believed to dispel/kill bacteria and viruses as a cause of the plague and coconut coir smoke, betel leaves and lanra 'are then placed in front of residents' doors so that bacteria and viruses as a cause of disease outbreaks can be dispelled. The Assongka Bala ritual is usually performed at sunset (day and night transition) which is believed to be the best time to dispel the plague of the disease. in the Assongka Bala ritual, bananas are first cleaned (washed and circumcised at the edges) as a form of belief that to repent and ask for help for the Creator, it must be done in a holy and clean condition.

In today's modern life, it will be explored whether Assongka Bala as one of the values and local wisdom systems of the community in the past is still held and practiced in the social life of the Bugis-Makassar community as is the case with several other forms of local wisdom (handyman, Sanro, jampi) spells, etc.) At present, various cities and countries around the world are affected by the Pandemic outbreak which is very frightening and causes significant death tolls and impacts on various life and economic activities where there is a relevance of the traditional value system practices of Assongka Bala to the Pandemic handlers in the modern life of the Bugis people- Makassar in terms of values, methods, the involvement of community components.

\section{Methods}

The method used in this research is a qualitative method with a descriptive design, which explains the handling of disease outbreaks in the Bugis-Makassar community from a cultural perspective. define qualitative methodology as a research procedure that produces descriptive data in the form of written or oral words from people and observable behavior.

Nine informants had been interviewed, there was a Customary Figure, who was the initial informant who was met and he also recommended some Sanro names, this research interviewed two Sanro, researchers chose the two Sanro because based on the results of the interview they gained knowledge in different ways, Another informant was the first medical person, a modern health profession (doctor, nurse, and pharmacist). The reason for choosing this informant was that knowledge about the prevention and treatment of different disease outbreaks. 
As this research, the authors conducted observations and interviews using interview guidelines that had been prepared previously. Data analysis begins by examining all available data from various sources, namely interviews, observations written in the diaries in the field, the results of observations and others (Creswell, 2012). After all the data has been collected, the first step that will be taken is to process the data, starting from the categorization of data classification by classifying the data according to the research question and then proceeding with data reduction, which is selecting data and sorting out which ones are considered important and then taking keywords from the data.

\section{Results and Discussion}

\section{Local wisdom contained in the Assongka Bala ritual}

One of the beliefs of the Bugis-Makassar community is based on the values of trust or ritual, especially related to handling disease, forming the perception that if the ritual is not implemented it will get individual sanctions/losses in the form of illness. Some of the values and norms that govern disease management, namely "if you want to be healthy, then work and eat what you plant". Therefore, most of the Bugis-Makassar people work as rice and garden farmers. Each head of a family grows rice and vegetables. Farmers are not allowed to use pesticides so that the rice and vegetables produced are free of toxins that can cause disease.

In Assongka Bala the ritual of making offerings is individual, only representative of each household. The ritual activity begins with the preparation of offerings in each house. Every household prepares material. The offerings (individuals) were then handed over to traditional leaders who had been waiting at the ceremonial place believed to be their ancestral place and stretched mats as a place where they sat doing rituals.

After all the residents are expected, the ritual leaders, in this case (as traditional leaders) start greeting residents by asking if all are present and confirmed by the residents. Then the ritual leader takes a position facing the tree and is accompanied by three other traditional figures. The four sat cross-legged and in front of them, each had a tray filled with incense, large leaves, betel leaves and yam (clay jug). As mentioned earlier, the Assongka Bala ritual performed by the Bugis-Makassar community is very simple. But behind his intelligence it contains a value called local wisdom.

The following is a description of some of the local wisdom found in the Assongka Bala ritual: One of the local wisdom found in the Assongka Bala ritual is simplicity. That is reflected in the menu (offerings) prepared by them. a high level of togetherness in this Assongka Bala ritual. Communities with their own awareness without being sent invitations or messages together to attend the ritual. This attitude is based on the thought that the rituals that they do belong together so there is no need to invite and invite. In addition, for togetherness they are willing to leave all their respective activities. At the time of the ritual, there was nothing important other than attending the Assongka Bala ritual. That is, the community still maintains the attitude of placing a common interest above personal interests.

Respecting their ancestors is the cause of their presence on earth, especially in Bugis-Makassar. Where they will never be called the Bugis-Makassar community. With that, in every breath and every behavior, they never forget their ancestors. Implementation of their honor to their ancestors. A belief that even though their ancestors are gone, there is an invisible force that is the source of their strength. The message captured that respects the services of others is commendable. No matter how small the service of people either for other people or for the nation must be respected. Form the belief of the Bugis-Makassar community that there is no other place to hide and ask except for Allah SWT. To him, the man gave up. This can be seen 
in the prayers said during the ritual. Assongka Bala ritual which is an attempt to prevent all the dangers of anger, calamity, and disaster that can not be realized without the permission of the Almighty. Humans are limited to the medium of prayer and all decisions and certainty are in God.

\section{Bugis-Makassar Community Behavior System in Dealing with Disease Outbreaks}

In the traditional environment, the Bugis-Makassar community has a tradition of Assongka Bala. This tradition is believed to be a form of repelling reinforcements, preventing the arrival of the disease, a bearer of fortune, simplifying matters, providing safety, longevity, and fertilizing the soil. Assongka installation customary rituals are routine traditional rituals where they are held once a year in June (one / January). Assongka Bala is a traditional ritual that uses ingredients from spices that grow in Bugis-Makassar both leaves with various types. The procedure for picking leaves has certain techniques/rituals based on directions from Sanro. Sanro ordered women and men to take lanra leaves. Women are in charge of picking leaves and men who bring the leaves to rituals are held and handed over to Sanro.

The Assongka Bala ritual procession is held on a good night during the full moon for 4 days, 4 nights. This procession is a traditional party ritual which is complemented by traditional food such as songkolo le'leng (black sticky), songkolo eja (red sticky), songkolo pute (white sticky), manu (chicken), loka (banana), kaluku (coconut), and old '. After the ritual is finished, the leaves are given to each house to be hung in front of the door. Every house has a sign at the entrance if the house has carried out this ritual.

In addition to carrying out the traditions of Assongka Bala, traditionally the community protects themselves from the disgraceful actions regulated by adat in rituals. Pangadakkang (adat) applies when the community violates or commits a despicable act. This can cause diseases that cannot be detected by modern medical science. Society recognizes it as a special disease because of mistakes. It is said that the disease can be treated but cannot be cured and is very susceptible to an unnatural death. These diseases such as leprosy which are hereditary up to two times seven generations, the body is swollen and blackened, broken bones, accidents, and when he died his body suddenly decayed and blackened, Pangadakkang form as follows:

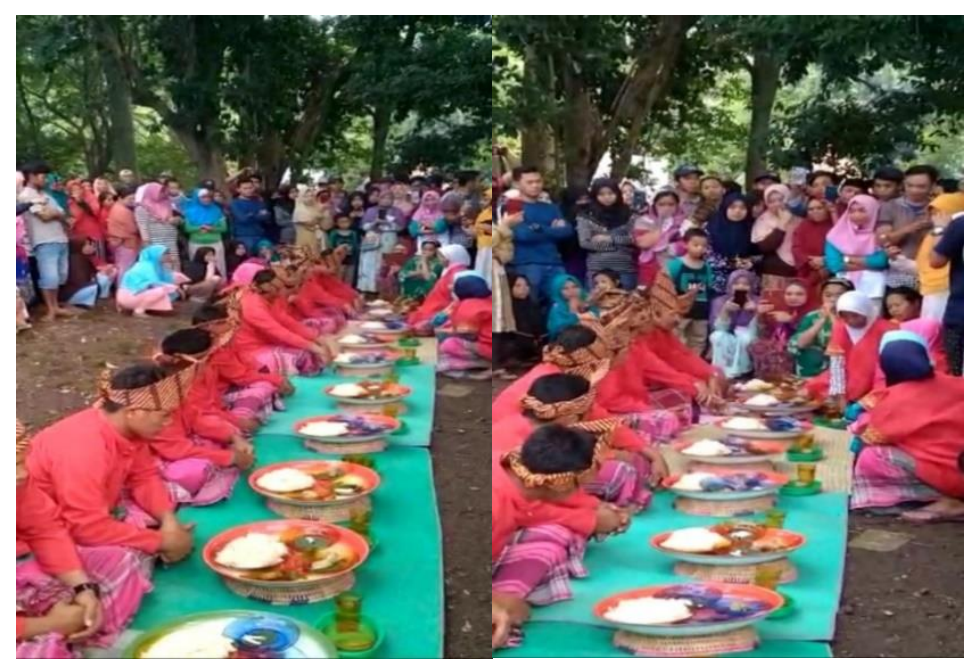

Figure 2. Pangadakkang

Image Source: Researcher 
The tradition is related to Adat to protect themselves from disease outbreaks, namely the Akkallabua ceremony. The timing of this ceremony is uncertain, but the main motive for its implementation is a rejection of reinforcements or an attempt to avoid something disruption of this disease is a traditional form of self-isolation. Intended diseases such as infectious diseases such as tuberculosis or other skin diseases. So this ceremony is also indirectly part of the practice of isolating forms of treatment in the traditional order of the Bugis-Makassar community.

\section{Healing methods: Sanro and Herbal Medicine}

Meanwhile, the concept of healthy and sick in the socio-cultural understanding of the BugisMakassar community in South Sulawesi Province is as follows. Their perception of illness is expressed in various terms used in daily conversation, such as malasa, madoko, makdokkong. These words refer to the concept of pain which means a person's condition or physical condition is not balanced. In their understanding, the imbalance experienced by a person is caused by two factors, namely: internal factors (influences originating from within individuals) and external factors (influences that come from outside). According to them the first factor is caused, among others, by the condition of organs that are not functioning properly, or can also be caused by hereditary factors. Meanwhile, external factors, caused by several elements such as an outbreak of disease that attacks, climate change or air temperature conditions, disturbance of spirits, poisoning, and various elements caused by environmental damage including the actions of fellow humans.

According to them, the human body in the form of the body is a combination of four natural substances, namely earth, water, wind, and fire, while the spiritual aspect is known as sumangek (sukma). The soul that is in the human body is seen as only staying for a while, and will separate when the person dies. The event of death itself causes all elements of the human body to return to its origin or the mortal realm, while the soul will remain alive and continue the process of life in the eternal supernatural. By this view, the concept of cultural knowledge of the Bugis-Makassar people specifically related to the term "sick" is nothing but referring to the existence of an unstable physical condition, due to the disruption and dysfunctional nature of natural substances contained within humans themselves.

Here is the real importance of integrating magic, religion, and science. So that formed a form of treatment that complement each other. A modern healer must be in charge of magic and religion. So that at one time it could be used in medical practice. Moreover, religion is needed in the healing process as Gustav Jung did in his treatment. Religious spirituality can affect the healing process. Psychologists see this phenomenon, essentially as a stimulant to cure sick patients. The most important element of religion must be integrated, namely the spiritual aspects of religion itself. Several spiritual elements are often needed in medicine including; 1) Confidence in healing, and patience in accepting illness, 2) Obedience to the creator and ancestral spirits, and 3) Prayer to the creator. See Figure 1 where Magic, Religion, and Science are integrated to produce discoveries that will be available now. 


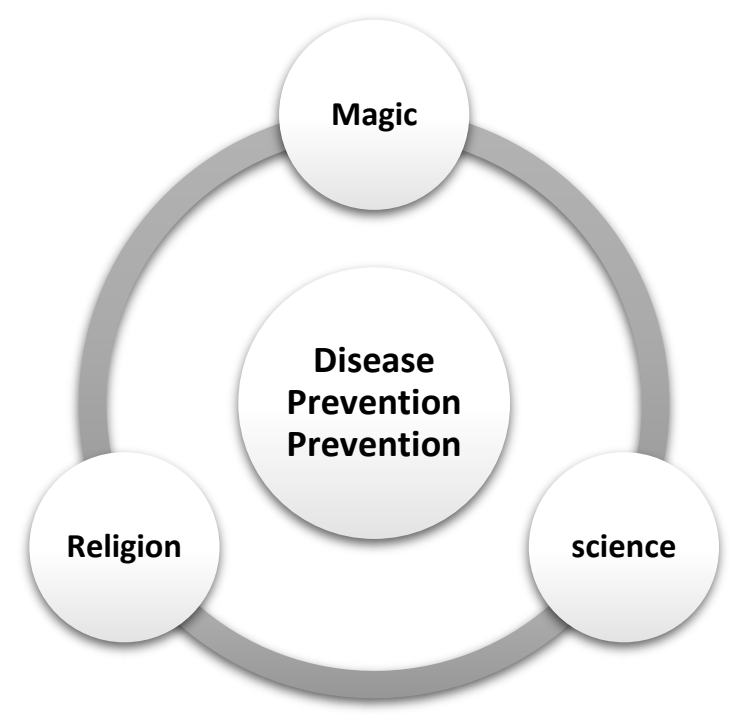

Figure 3: Treatment of 3 Layers

Source: Researcher data

The Bugis-Makassar community believes that outbreaks of disease can come from God and humans. The community believes that if God gives disease, then it also surely provides a cure that can be obtained from nature. People use plants that are planted around the house to cure a disease. This plant is called the paisenna to rioloa plant, which is a plant used by ancestors in healing. The process of taking medicinal plants also has rules. This process is carried out when the plants have not wilted or at 06.00-08.00 which was preceded by praying to take medicine.

The meaning of the prayer is an intention/request to nature to take leaves, roots or stems for the treatment of certain diseases, in this case, the name of the disease to be cured is mentioned in prayer. After reciting a prayer, if it has received a response from nature that is interpreted by Sanro as permission from nature to take part in the tree as medicine. After being taken, in general, the medicine is processed by using warm water mixed with plant material taken previously. Also, the drug can be kneaded and applied to the affected part.

In reference, traditional knowledge about medicinal plants and treatment procedures in South Sulawesi Province is inseparable from the important role of a Sanro. He is a clever or local scholar who acts as a helper and seeks to heal people who are sick. In general, the traditional healer is not a paramedic who has formal education in the health sector, but an ordinary community member who has expertise and ability in the field of traditional medicine. He also According to know the various types of plants that can be used to treat certain types of diseases. Thus, it is certain that a Sanro will have a large collection of medicinal plants. In practice, local people group Sanro into several categories such as (a). Sanro tolo, or baby placenta cutter. (b). Sanro pabbura-bura, an expert in treating various diseases with herbs. (c). Sanro pajjappi, treats through the reading of spells. (d). Sanro tapolo, an expert in healing and healing fractures, through the practice of massage and reading of spells and (e) Sanro pattirotiro, traditional healers who focus on treatment efforts through divination/fortune telling.

According to the cultural concept of the Bugis-Makassar Sanro is not only known as a person who can assist the sick who come to him through medical practices, but Sanro is also known as a person who can control and even carry out the extinction of certain diseases. Thus Sanro has a broader understanding, meaning that it is not just a traditional healer. Citizens in BugisMakassar said that Sanro can be called a traditional healer because his ability is not limited to 
knowledge of herbal ingredients (herbs) but also the ability to heal with the prayer system and spells.

A Sanro said that in the treatment of epidemics there is a disease. Where every disease has a certain medicine and treatment materials usually use lanra leaves', coconut fiber and tree roots to be burned in incense forms of fumigation and prevention of disease so as not to spread to others around it. Sanro said 'even almost all plants can be used as medicine if the benefits are known. Every Sanro generally uses a tool to put incense, which is a container made of copper/clay. In the container, usually, there is charcoal, leaves, and badik. To treat a prayer, first, burn incense using the container.

Most of the houses in the Bugis-Makassar community have medicinal plants in their homes. When hearing an outbreak of a contagious disease and before leaving for Sanro, the community can prevent the disease by burning the plant and storing it in front of the house or the main door is a form of community values in the prevention of outbreaks and traditional medicine. Communities can pick directly available medicinal plants in their home yards. Knowledge of various medicines for the disease was obtained from the Sanro people or their ancestors. So that the community can prevent and treat their disease without having to go to Sanro.

\section{Conclusion}

The Bugis-Makassar community, in their practice of life, is related to the social, cultural and handling of disease outbreaks, the community has a belief in the rituals of Assongka Bala which then becomes traditional values that affect their knowledge about handling epidemics and also influences their behavior in maintaining health, namely the behavior system is generally divided into two types, namely in the family environment and customary environment. Assongka Bala rituals are manifested in the form of offerings and prayers to the Almighty. In the recitation of prayers led by their traditional leaders is a picture of the belief that there is no place to ask and ask except to Allah alone. Apart from that, it is only to God that all strength and protection are gained. Simplicity becomes an important point that colors the Assongka Bala ritual. Homely simplicity and full of intimacy and sense of family. Togetherness binds them strongly in family ties. Togetherness between them can eliminate all kinds of differences both in terms of material and social stratification. Adherence to customary rules and norms breeds mutual respect among people. They will know the boundaries between rights and obligations. Likewise, respect for ancestors breeds mutual respect in daily life. And as a human being created by God should be submitted to the Almighty. This attitude will give birth to humility and away from pride and arrogance. Values that begin to become local wisdom as described above are expected to not only color life, but that it can be a color in building the life of the nation and state.

\section{References}

Creswell, J. W. (2012). Research Design Pendekatan Kualitatif, kuantitatif, dam mixed. Yoyakarta: Pustaka Pelajar.

Hadisaputra, H. (2016). Relasi Agama, Magi Dan Sains Dalam Pentas Politik: Studi Kasus Bunda - Sang Penasehat Spiritual. ETNOSIA: Jurnal Etnografi Indonesia, 1(1), 1529. https://doi.org/10.31947/etnosia.v1i1.994

Hasbullah, H., Toyo, T., \& Awang Pawi, A. A. (2017). Ritual Tolak Bala Pada Masyarakat Melayu (Kajian Pada Masyarakat Petalangan Kecamatan Pangkalan Kuras Kabupaten Pelalawan). Jurnal Ushuluddin, 25(1), 83. https://doi.org/10.24014/jush.v25i1.2742 
Jannah, N. I. A. U., \& Zurinani, S. (2017). Pewarisan ilmu dukun dalam sistem penyembuhan tradisional. Masyarakat, Kebudayaan dan Politik, 30(1), 48-58. https://doi.org/10.20473/mkp.v30i12017.48-58

Kusumah, D. (2017). Pengobatan Tradisional Orang Bugis-Makassar. Patanjala: Jurnal Penelitian Sejarah Dan Budaya, 9(2), 245. https://doi.org/10.30959/patanjala.v9i2.22

Laila, A. (2018). Tradisi Selamatan Tolak Belek Di Desa Pulau Harapan Kecamatan Sembawa Kabupaten Bayuasin. Diploma thesis, UIN Raden Fatah Palembang.

Oktaviani, D. J., Widiyastuti, S., Maharani, D. A., Amalia, A. N., Ishak, A. M., \& Zuhrotun, A. (2019). Review: Bahan Alami Penyembuh Luka. Farmasetika, 4(3), 44. https://doi.org/10.24198/farmasetika.v4i3.22939

Rismawati, R. (2014). Tradisi Songkabala di Kecamatan Sanrobone Kabupaten Takalar (Suatu Kajian Sosio-Kultural). Rihlah: Jurnal Sejarah dan Kebudayaan, 2(01), 118-835.

Teng, M. B. A., Rijal, S., \& Badollahi, M. Z. (2019). Discourse Analysis of Kajaolaliddong Pappaseng in the Formation of Student Characters in a Model School in the District of Bone. People: International Journal of Social Sciences, 5(3), 432-441. https://doi.org/10.20319/pijss.2019.53.432441

Yakub, I. (1972). Sejarah Islam di Indonesia. Jakarta: Proyek Pengadaan Bahan Dakwah Depag RI 1972. 